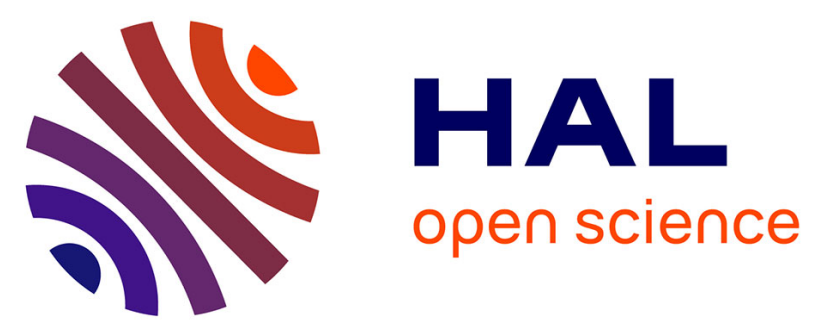

\title{
NiTi based stent for the treatment of acute urinary retention due to benign prostatic hyperplasia: a preliminary study on NiTi wires and tubes under pure bending
}

Gabriel Antherieu, Nathanaël Connesson, Yohan Payan, Denis Favier, Pierre

Mozer

\section{To cite this version:}

Gabriel Antherieu, Nathanaël Connesson, Yohan Payan, Denis Favier, Pierre Mozer. NiTi based stent for the treatment of acute urinary retention due to benign prostatic hyperplasia: a preliminary study on NiTi wires and tubes under pure bending. Computer Methods in Biomechanics and Biomedical Engineering, 2014, 17, pp.190 - 191. 10.1080/10255842.2014.931679 . hal-01108621

\section{HAL Id: hal-01108621 \\ https://hal.science/hal-01108621}

Submitted on 23 Jan 2015

HAL is a multi-disciplinary open access archive for the deposit and dissemination of scientific research documents, whether they are published or not. The documents may come from teaching and research institutions in France or abroad, or from public or private research centers.
L'archive ouverte pluridisciplinaire HAL, est destinée au dépôt et à la diffusion de documents scientifiques de niveau recherche, publiés ou non, émanant des établissements d'enseignement et de recherche français ou étrangers, des laboratoires publics ou privés. 


\title{
NiTi based stent for the treatment of acute urinary retention due to benign prostatic hyperplasia: a preliminary study on NiTi wires and tubes under pure bending
}

\author{
G. Antherieu* $\dagger$, N. Connesson $\dagger$, Y. Payan $\dagger$, D. Favier $\dagger$, P. Mozer $\ddagger$ \\ † Laboratoire TIMC/IMAG, UMR CNRS 5525, Faculté de Médecine Domaine de la Merci, La Tronche, France
}

†ISIR/service d'urologie, hôpital la Salpêtrière, 37, boulevard de l'Hôpital, 75013 Paris, France

Keywords: NiTi; BPH; Bending; Wire; Tube

\section{Introduction}

Benign prostatic hyperplasia (BPH) remains an incompletely understood disease, mostly striking old men. In fact, $40 \%$ of men over 50 show evidence of $\mathrm{BPH}[1]$. The main consequence of $\mathrm{BPH}$ is an uncontrolled growth of prostate epithelial and stromal tissues. Eventually, this may lead to an acute urinary retention (AUR) [2], calling for an emergency treatment. Today, the first line treatment consists in emergency catheterization. However, catheterization is responsible for $80 \%$ of nosocomial urinary tract infections (NUTIs); with NUTI risk increasing by $3 \%-10 \%$ a day [3]. As an alternative to catheterization, an innovative $\mathrm{NiTi}$ shape memory alloy (SMA) based stent, made of a helical wire inserted into a helical tube was developed. In particular, this stent presents at least two distinct successive shape memories during heating, allowing an extension phase to release the urethra, and a contraction phase for an easy removal. This paper presents the stent mechanism, and the first mechanical characterization of the NiTi wires and tubes, under pure bending.

\section{Methods}

SMAs show very different mechanical behaviours according to their temperature. These behaviours have been widely studied and reviewed in the literature [4]. Essentially, every SMA sample is given a transition temperature $\mathrm{T}_{\text {trans }}$, and a set shape, which can be adjusted through appropriate thermal treatments. Under this temperature $T_{\text {trans }}$, SMA is in a martensitic state, its elastic modulus is lowered, and it shows pseudo-plasticity around $8 \%$ strain. In particular, SMAs are able to recover their set shape when heated above $\mathrm{T}_{\text {trans }}$.

A NiTi wire, diameter $0.5 \mathrm{~mm}$, was given a helical shape at diameter D1, and a $\mathrm{T}_{\text {trans }}=\mathrm{T}_{1}$ (Fig.1.a). A $\mathrm{NiTi}$ tube, inner diameter $=0.5 \mathrm{~mm}$ and wall thickness $=0.05 \mathrm{~mm}$, was given a helical shape at diameter D2 $>$ D1, and a $\mathrm{T}_{\text {trans }}=\mathrm{T}_{2}<\mathrm{T}_{1}$ (Fig.1.b). To achieve a complex one-way shape memory stent, the wire was then inserted inside the tube. The stent obtained this way shows three different behaviours and shapes, according to its temperature $\mathrm{T}_{\text {stent }}$ :

- $\mathrm{T}_{\text {stent }}<\mathrm{T}_{2}<\mathrm{T}_{1}$ : both elements are in martensitic state, the stent can be easily reshaped at different diameters (Fig.1.c).

- $\mathrm{T}_{2}<\mathrm{T}_{\text {stent }}<\mathrm{T}_{1}$ : The wire remains in martensitic state whereas the tube is activated and tries to recover its set shape, expanding the stent (Fig.1.d).

- $\mathrm{T}_{2}<\mathrm{T}_{1}<\mathrm{T}_{\text {stent }}$ : both elements are activated, but strength applied by the wire is superior to the one applied by the tube, thus the stent is contracting (Fig.1.e). NiTi wire

(a)

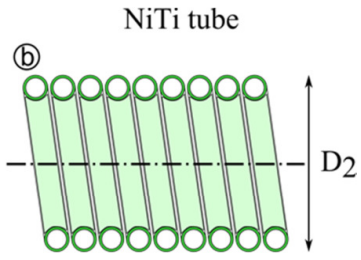

(C)
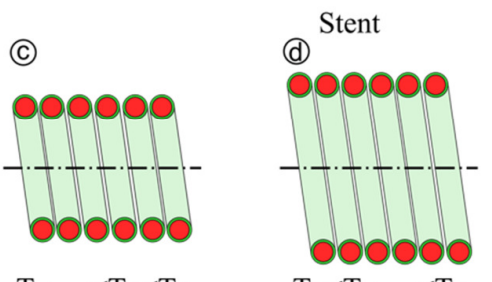

(e)

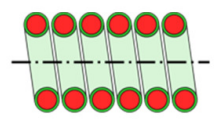

$\mathrm{T}_{\text {stent }}<\mathrm{T}_{2}<\mathrm{T}_{1}$
$\mathrm{T}_{2}<\mathrm{T}_{1}<\mathrm{T}_{\text {stent }}$

Figure 1:The stent and its various configurations

The stent is given a helical shape. However, unlike a typical compressed helical spring, where wire is mostly loaded in torsion, the stent diameter is changing during expansion (or contraction). For this reason, both the wire and the tube are mostly loaded under bending when the stent is expanding or contracting. In order to design a stent that will interact with the prostate tissues with proper extended and contracted diameters, the behaviour of NiTi wire and tube was investigating under pure bending. NiTi materials present tensioncompression asymmetry [5,6], which makes bending behaviour difficult to predict. A specific 

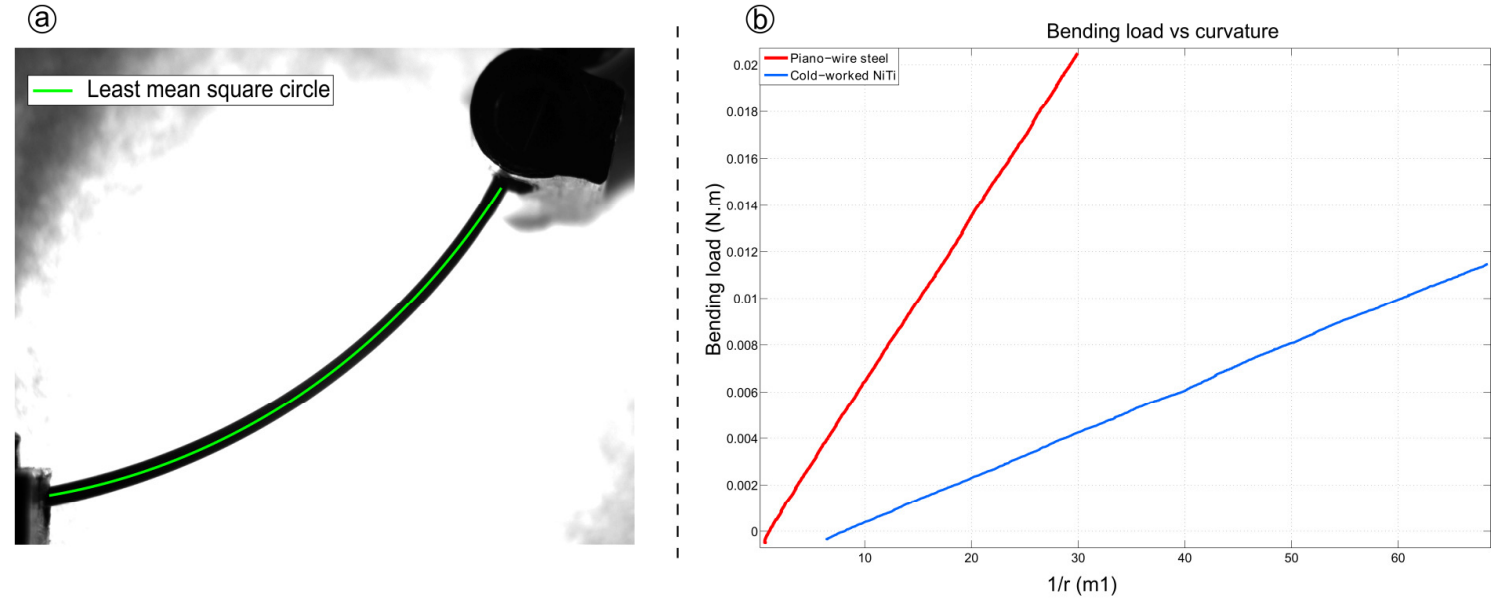

Figure 2: a-Photograph of the bengin test with its least mean square circle ; b-Results for cold-worked NiTi wire and steel wire

apparatus has been designed. It enables pure bending testing with a wide range of radii of curvature (from a linear geometry to $1 \mathrm{~cm}$ radius of curvature) on small samples (less than $1 \mathrm{~mm}$ diameter).

Steel wires diameter $0.5 \mathrm{~mm}$, NiTi wires and tubes described before, length $2.5 \mathrm{~cm}$, were tested under bending load, for a radius of curvature reaching about $1.5 \mathrm{~cm}$. Various thermal treatments and testing temperature were used, providing results for different crystallographic states: cold-worked, martensitic and austenitic. Testing was carried out on a Gabo Eplexor $500 \mathrm{~N}$ equipped with a $25 \mathrm{~N}$ load cell at $\dot{\varepsilon}_{\max }=0.01 \% . \mathrm{s}^{-1}$. Maximum strain reached was $\varepsilon_{\max }=1.75 \%$ for NiTi samples and $\varepsilon_{\max }=0.75 \%$ for steel samples. Pictures of the loaded sample were taken during the testing (Fig.2,a). Radius of curvature was then determined through these pictures, using an in-house program to fit a least mean square circle on each picture (Fig.2,a).

\section{Results and Discussion}

Experiments on steel wires were used to validate the bending apparatus. Since steel samples were tested in their elastic field, bending load is supposed to increase linearly with curvature. Results obtained for steel wires (Fig.2,b, red) show a good linearity, as predicted by the theory. The Young modulus was determined as E=220GPa, which is a common value for piano-wire steel. First results obtained for cold-worked NiTi wire (Fig.2,b, blue), show a good linearity too, and provides a first measurement of Young modulus, $E=62 \mathrm{GPa}$, which is consistent with the literature (Fig.2,b) [4]. These results confirm the ability of the bending apparatus to provide tested material mechanical behaviour under pure bending.

Further experiments on NiTi should be carried out, to investigate specific phenomena that have recently been mentioned in the literature, such as localization[7].

\section{Conclusions}

Bending tests at low radius of curvature were performed on $\mathrm{NiTi}$, using an innovative bending apparatus. This gave first characterization of NiTi behaviour under pure bending, and provided useful information on NiTi behaviour under compression.

\section{Acknowledgments}

This work has been supported by the LABEX CAMI (Ref. ANR-11-LABX-0004).

\section{References}

[1] McNicholas T. 2011. Benign prostatic hyperplasia. Surgery (Oxford). 6:282-286.

[2] Schneider T. 2008. LUTS suggestive of BPH: prevention or retention? European Urol Supp. 7:696-701.

[3]Alfandari S. 2003. Prevention of nosocomial urinary tract infections: influence or urinary tract infection on length of stay, cost and mortality. Médecine et maladies infectieuses. 33:247-254.

[4]Otsuka K., Ren X. 2005. Physical metallurgy of Ti-Ni based shape memory alloys. Progress in Materials Science. 50:511-678.

[5]Orgeas L, Favier D. 1998. Stress-induced martensitic transformation of a NiTi alloy in isothermal shear, tension and compression. Acta materiala. 15:5579-5591.

[6]Grolleau V, Favier D. 2011. Assessment of tension-compression asymmetry of NiTi using circular bulge testing of thin plates. Scripta materialia. 4:347-350.

[7] B.Reedlunn, C.Churchill. 2014. Tension, compression and bending of superelastic shape memory alloy tubes. Journal of the mechanics an physics of solids. 63:506-537. 